\title{
O TESTEMUNHO EM TRÊS VOZES: TESTIS, SUPERSTES E ARBITER
}

\author{
Augusto Sarmento-Pantoja ${ }^{1}$
}

Resumo: Na tradição dos estudos sobre testemunho encontramos duas formas bem delimitadas de narradores, caracterizadas a partir dos estudos de Émile Benveniste (1969), e amplamente utilizados pelas pesquisas sobre o autoritarismo e a Shoah, que veem, no Brasil, as contribuições de Márcio Seligmann-Silva (2008) na fixação dos conceitos de testemunho testis e testemunho superstes. Na esteira desses estudos, proponho uma nova categoria de testemunho o arbiter, que se configura na narração realizada por meio da recuperação do testemunho ouvido. Por muito tempo, esse tipo de testemunho fora desvalorizado, por não representar as formulações tradicionais do testemunho testis (terceiro), aquele que viu e testemunhou a cena dolorosa, ou do testemunho superstes (primeiro), aquele que viveu e testemunha sua própria experiência. Compreendemos que o testemunho arbiter (segundo), daquele que ouviu e arbitra o que e como narrar, deve ser validado como parte de uma tríade testemunhal, já que se encontra imiscuído às outras formas de testemunho, pois a identificamos em narradores testis e superstes, ao descrever experiências de outros a ele contada. Essa categoria de testemunho também se apresenta no que chamamos de narrativa de segunda geração, dos filhos de sobreviventes, que na maioria dos casos narram por meio da reconstrução testemunhal das experiências de outros, ou dos testemunhos de outros, inclusive em relação a sua própria experiência

Palavras-chave: Testemunho; Testis; Superstes; Arbiter.

\begin{abstract}
In the tradition of the studies on testimony we find two well-defined forms of narrators, characterized by Émile Benveniste's (1969) studies, and widely used by research on authoritarianism and Shoah, which see in Brazil the contributions of Márcio Seligmann-Silva (2008) in setting the concepts of testimony testis and testimony superstes. In the wake of these studies, I propose a new category of testimony to the arbiter, which is configured in the narration performed through the recovery of the testimony heard. For a long time, this type of testimony had been devalued because it did not represent the traditional formulations of testis (third) testimony, that one saw and witnessed the painful scene, or the superstes witness (first), the one who lived and witnesses his own experience. We understand that the arbiter (second) testimony of the one who heard and arbitrate what and how to narrate must be validated as part of a testimonial triad, since it is involved in other forms of testimony, for we identify it in narrators, testis and superstes, when describing experiences of others told to him. This category of testimony also appears in what we call the second-generation narrative of the children of survivors, who in most cases narrate through the testimonial reconstruction of the experiences of others, or the testimonies of others, even in relation to their own experience.
\end{abstract}

Keywords: Testimony; Testis; Superstes; Arbiter.

Esse estudo fundamenta em uma contribuição para o conceito de testemunho, enquanto categoria chave para pensar a narração da memória traumática. Buscamos propor uma importante mirada sobre a teoria do testemunho na medida em que apresentamos ao leitor uma terceira categoria de narrador testemunhal aqui chamada de testemunho arbiter. O argumento consiste em relacionar essa forma de testemunho a narração de segunda pessoa, ligada à faculdade da audição e não mais a

\footnotetext{
${ }^{1}$ Doutor em Teoria e História Literária pela Universidade Estadual de Campinas (UNICAMP). Professor de Literatura em Língua Portuguesa na Faculdade de Ciências da Linguagem (Campus Abaetetuba) da Universidade Federal do Pará (UFPA) e também do Programa de Pós-Graduação em Letras (Campus Guamá) e do Programa de Pós-Graduação Interdisciplinar Cidades, Territórios e Identidades (Campus Abaetetuba), da mesma instituição. E-mail: augustos@ufpa.br
} 
visão como se dá no narrador testis ou a experiência e sobrevivência como no narrador superstes, como veremos a seguir.

A teoria do testemunho toma a etimologia do termo para construir um binarismo sobre o lugar de enunciação desses narradores. A narração testemunhal é sem dúvida uma alternativa de sobrevivência para quem viveu uma experiência limite, seja ligada à guerra ou aos conflitos políticos, étnicos ou de posse da terra. A classificação conhecida e referendada no testemunho está apoiada na proposição feita por Émile Beveniste (1969), que aponta duas formas de testemunho, uma ligada a posição de um narrador terceiro, o testis, e outra marcada pela posição de um narrador primeiro, o superstes, proposição amplamente discutida por Márcio Seligmann-Silva (2001, 2008), no Brasil. Nesse ensaio, propomos uma terceira forma de narrar, mediado pela fala do outro, também identificado nos estudos de Benveniste, mas por conta de sua natureza, mediada pelo ouvir e não pelo ver ou vivenciar, por muito tempo desprezada. A categoria que proponho como complementar aos estudos do testemunho é arbiter, conforme trataremos mais especificamente a frente.

Para início de conversa vejamos algumas considerações sobre o vocábulo testemunho. Originariamente, encontramos uma raiz latina em torno do vocábulo testis, is, que para Ernesto Farias (1962, p. 994) possui três acepções: “a) associado ao sentido próprio e figurado: testemunho, depoimento; b) no sentido particular, representa o expectador; c) no plural: testículos". Em seguida, o dicionarista apresenta os usos de outro verbo que nos auxiliaria a compreender o vocábulo, neste caso, testor, aris, ari, atus, que significam testemunhar; dar um testemunho, desdobrando-se em atestar, afirmar, declarar.

Vejam como o dicionarista descreve a primeira acepção. Para ele se faz centrada na ação testemunhal, ou seja, a narração, o testemunho enquanto materialidade, enquanto relato daquele aquele que é o primeiro a relatar; o que viveu a experiência e testemunha a partir da imersão nessa experiência e desse modo dá seu depoimento, chamado por Benveniste (1969) de superste, o que sobreviveu. Já, na segunda acepção, o testemunho se faz centrado na figura daquele que vê e presencia a ação. Aquele que viu; aquele que é a testemunha ocular tem também a chancela de dar o testemunho. Essa forma de testemunho se aproxima ao que Benveniste chama de testis, o terceiro, o que se propõe a testemunhar na condição de espectador. A última acepção de testis é no mínimo curiosa, pois se encontra no plural, quando as anteriores se referiam apenas ao singular, uma testemunha, esta terceira acepção nos traz a ideia do compartilhamento da ação testemunhal, fazê-los não mais segundo uma individualidade, mas em nome de uma pluralidade de vozes. Ao nos confrontarmos com o termo no plural, testículos, além de ser um termo inusitado, tivemos a curiosidade aguçada para a possibilidade de transformar o termo em um mote para pensar sobre a viabilidade de uma terceira categoria do testemunho. 
Nos perguntamos, considerando apenas o vocábulo testis, is, relacionado a testículos, como seria possível compreender o testemunho relacionando-o às glândulas seminais (gônadas masculinas)? Recorremos então à cultura da Antiguidade para tentar entender essa aproximação. Ao fazermos esse percurso nos deparamos com o fato de que entre gregos, romanos, egípcios, hebreus, mulçumanos e outros povos, as figuras femininas foram, historicamente, destituídas de direitos fundamentais para a cidadania, entre elas o testemunho. Entre as diversas explicações apresentadas, uma delas foi bastante recorrente, a subjugação cultural feminina se devia ao patriarcalismo, àquela altura justificado culturalmente e biologicamente. No âmbito cultural, destaca-se o fato da mulher não ter representatividade, como é o caso da posição social, que é herdada por sua relação com um homem. Sobre essa condição vejamos o que nos mostra o Corpus Iuris Civilis - Digesto,

Mulheres casadas com pessoas ilustres incluem-se na categoria de pessoas honoráveis, Não se considerarn como mulheres honoráveis filhas de senadores, a menos que casern com homens ilustres, pois os maridos transmitem as mulheres sua dignidade (DIGESTO, 2010, p. 88)

Certamente, neste tempo, a mulher pouco ou nada participava da estrutura política e administrativa daquelas sociedades, bem que desejavam, mas eram alijadas dos processos políticos, interdito imposto pela figura masculina, que determinavam o que e quem possuiria poder político. Como vimos, na passagem acima, até mesmo a reputação da mulher estava articulada a uma transmissão da parte do marido ou seu responsável. Na exegese grega encontramos outras proposições próximas a esta romana, como na passagem da Ética a Nicômaco, de Aristóteles:

\begin{abstract}
A associação entre marido e mulher parece ser aristocrática, já que o homem governa como convém ao seu valor, mas deixa a cargo da esposa os assuntos que pertencem a uma mulher. Se o homem governa em tudo, a relação degenera em oligarquia, pois ao proceder assim ele não age de acordo com o valor respectivo de cada sexo, nem governa em virtude da sua superioridade. (ARISTÓTELES, 1991, p. 187)
\end{abstract}

O governo das relações patriarcais impõe à mulher uma posição subalterna evidente, por isso, em várias dessas formulações, o direito a fala (do testemunho), não seria para todos e interditado às mulheres. O discurso da busca pela cidade perfeita e a igualdade de direitos no Livro V em A República de Platão nos mostra o quanto a cultura helênica considerava a mulher subalternizada:

Sócrates - Tens conhecimento de alguma atividade humana em que os homens não sobrepujem as mulheres? Estenderemos o nosso discurso mencionando a tecelagem, a confeitaria e a cozinha, trabalhos que parecem apropriados às mulheres e em que a inferioridade dos homens é altamente ridícula? (PLATÂO, 1997, p. 154) 
Vemos na proposição de Sócrates novamente uma espécie de relação de atividades que relega a mulher ao espaço doméstico, delegando ao homem superioridade em todas as outras áreas, inclusive a política. A supremacia masculina é colocada nesses tempos em torno da biologia mínima, ser homem ou ser mulher. Por isso, não adiantava conhecer e poder dizer, o narrador precisava possuir o instrumento biológico da ação testemunhal: os testículos. Obviamente, se faz implicado nesse processo o poder de disseminação da herança patriarcal, um discurso que por incrível que pareça ainda reverbera hoje, não que concordemos, mas que ainda se faz contemporâneo.

Considerando, então, esse sentido primariamente biológico, o fundamento do testemunho surge relacionado a uma dádiva divina entregue ao homem, pois ele seria o responsável pela perpetuação da espécie $^{2}$. Dessa forma, essa constituição cultural associada à fixação da máxima teológica do "crescei e multiplicai-vos", potencializou o discurso do poder viril delegado ao gênero masculino, já que possuidor do testículo e do phallus (pênis). A soberania masculina observa o ser humano no topo da cadeia dos seres vivos, mas com diferenças marcantes entre o homem e a mulher, como destaca Ana Paula Vosne Martins (2000, p. 20):

A interpretação dada por Aristóteles e depois por Galeno é que no ápice da cadeia dos seres vivos estava o homem, por sua natureza quente e seca, seguido da mulher, hierarquicamente inferior por ser considerada mais fria e úmida. Para este pensamento cuja a vitalidade é assombrosa, o que diferenciava o homem da mulher não eram as características sexuais do corpo, mas uma noção de perfeição baseada no calor vital. O corpo feminino era a expressão da imperfeição porque seus órgãos sexuais eram invertidos, já que não tinha calor suficiente para exteriorizá-los como o homem.

Para os limites da argumentação que levantamos essa diferença mostra uma história da humanidade que delega ao feminino a uma posição de inferioridade e subalternidade, justificando assim a impossibilidade da mulher testemunhar. Retomando a etimologia médica do termo "testículo", encontramos a seguinte caracterização:

Diminutivo do latim Testis, que tinha a significação de 'pote de pequeno tamanho'. A palavra Testis era empregada na acepção de 'testemunha'. Entre os senhores e os servos havia o hábito de fazer juramento ou testemunho de fé segurando os testículos, sendo que este costume existiu entre os indus, egípcios e hebreus. Na antiga Roma, a lei exigia que, na Júris, o indivíduo mostrasse seus testículos. O testículo testemunha também a existência da virilidade. Herófilo acreditava que os filhos varões viriam do testículo direito, geralmente maior, mais pesado, mais baixo, e, segundo a crença, mais vascularizado. Galeno também acreditava nesta teoria e propunha, curiosamente, algumas manobras sexuais para garantir o sexo do futuro descendente, pois para os

\footnotetext{
${ }^{2}$ Temos que notificar que a biologia da mulher não seria conhecida internamente, antes do século XV, ao ponto de somente em 1480 a medicina começar a utilizar o termo ovário para designar a gônada feminina. Até aquele momento, era utilizado o termo testículo para ambos os sexos. Ver Martins (2000, p. 21).
} 
povos antigos o sexo do recém-nascido dependia de quem, no casal, alcançava primeiro o orgasmo. (SIMÕES, [et. al.], 2014, p. 88)

Vimos, na caracterização médica, a importância atribuída ao testis, enquanto parte da cultura da Antiguidade e da manutenção das relações de poder, de fidelidade e de hereditariedade. Quanto à manutenção do poder, destacamos ainda a necessidade da família ter filhos homens, por isso, a necessidade de manutenção do homem como o detentor do direito e a perpetuação da espécie. Daí a aceitação de uma cultura poligâmica responsável por criar uma espécie de supremacia masculina, livre para se relacionar com várias mulheres, como ainda hoje ocorre em várias culturas.

O termo "testículo" também se encontra arrolado à manutenção e valorização da fidelidade, neste caso destacamos como representante dessa forma de entender o testis os episódios em que estão representadas a submissão do servo aos seus senhores, quando estes exigiam não apenas a palavra do servo, mas também uma prova de sua fidelidade, marcada pela humilhação diante do senhor, quase sempre, em nome do Deus. Nesse processo, o submisso servo dá um testemunho de fé, como um atestado, uma afirmação, uma declaração de lealdade para com seu o senhor, posto em cena como rito ao se submeter a tocar nos testículos de seu senhor, ou expô-los em público. A prova da submissão se faz exatamente no fato do servo tocar os testículos do senhor como prova de aceitação de sua insignificância diante de seu mestre. Observa-se desse modo como se constitui culturalmente na Antiguidade o atestado de verdade daquele que testemunha e de como esse processo esteve associado à autoridade masculina e no cerne da tradição patriarcal, por esse motivo, quanto mais homens em uma família, mais poder de testemunho esse grupo possuiria, portanto, nesse sentido, em seus primórdios o testemunho teria como função social integrar e fortalecer as relações intergrupais e, principalmente, consolidar um modelo de governabilidade baseado na soberania.

Importante salientar que entre os romanos o costume sofre modificação, na medida em que deixa de se referir ao outro e passa a se referir a si. Com essa transformação é como se estivéssemos diante de duas formas do testemunho: uma ligada à submissão ao senhor, na encenação do testemunho como prova de verdade (da lealdade) para com o outro, daí a necessidade de ir ao testis (ao testículo) de seu senhor. Outra ligada ao testemunho de si. Nessa, o servo precisa expor-se, não mais pelo outro, mas por si mesmo, para que todos possam entender que o testemunho, agora mais próximo da encenação de um ato de fala, é prova de verdade, ao ponto de se expor em público. Daí parece derivar os fundamentos da matriz performática da ideia de testemunho como o conhecemos na atualidade, bem como suas dimensões políticas e éticas, especialmente demarcadas a partir do século XX: superexposição, sobrevivência, compartilhamento, superstes. 
Essa exposição revela a posição do narrador terceiro, que em sua narrativa se faz marcar ainda pelo caráter exemplar da verdade implicada em seu testemunho, pois ele precisa deixar evidente que ao expor em público a história que conta ele mostra seu compromisso com a verdade. Grosso modo, podemos dizer que o testemunho passa a representar uma prova de lealdade para com alguém ou algum fato ou promessa, associando o homem que testemunha à submissão ética e religiosa. Por isso temos uma relação plural, em que o testemunho não é mais marcado apenas por um personagem, mas pela relação íntima entre duas ou mais personas.

Dar o testemunho sobre a experiência do outro representa questionar a si mesmo sobre suas percepções. Ser o terceiro, o testis, a testemunha ocular, já representa um desafio imenso para o indivíduo, imagine se o testemunho for dado por aquele que viveu a experiência. Nesse caso a etimologia do termo testemunho revela a existência de outro termo para designar um auto-testemunho, a narrativa de si, a sobrevivência, supērstēs, tĭtis. No sentido etimológico, temos aquele "que está ou fica em cima"; já em um sentido próprio é aquele "que sobrevive, que resta, que ainda dura"; por fim em sentido particular se define como o "presente, testemunha” (FARIA, 1962, p. 969).

Todas as acepções de supērstēs, tĭtis, fazem-nos refletir sobre a tarefa de testemunhar, pois para o sobrevivente testemunhar significa "estar ou ficar em cima” das memórias do evento traumático. Neste sentido, só há testemunho quando se constroem estratégias psíquicas para suportar as memórias aterradoras do evento, sem que elas sejam superadas, curadas ou desapareçam. Somente nesta condição é possível perlaborar ${ }^{3}$ o trauma, como nos aponta Joselina Rodrigues Rodovalho, ao observar que

\begin{abstract}
A perlaboração é um conceito freudiano que relaciona o sujeito à sua própria enfermidade, concernindo-o apropriadamente na decifração de seus sintomas somáticos e psíquicos (processo de cura), mantendo no terreno das representações psíquicas, os impulsos pulsionais que tendem fortemente a derivações inconscientes em atos sintomáticos, compulsivos e repetições reprodutivas. (2006, p. 3)
\end{abstract}

\footnotetext{
${ }^{3}$ O termo perlaboração aparece nos estudos de Sigmund Freud com o vocábulo Durcharbaitug. Entretanto as duas traduções brasileiras desconsideram o termo e passam a tratar por elaboração, que para nós apresenta-se equivocado. Na tradução mais recente de Paulo Cesar de Souza, há uma nota referindo-se à existência do termo perlaboração, mas opta por utilizar o termo elaboração por considerar "palavra estranha". Identificamos no Vocabulário da Psicanálise, de Laplanche e Pontalis (1996, p. 429;430) a justificativa para utilizarmos o termo perlaboração (perlaboration) ao invés de elaboração (élaboration). Para esses autores, "tratar-se-ia de uma espécie de trabalho psíquico que permite ao indivíduo aceitar certos elementos recalcados e libertar-se da influência de certos mecanismos repetitivos", ou ainda "a perlaboração constitui facto propulsor do tratamento comparável à rememoração das recordações recalcadas e a repetição na transferência". Desse modo, o uso do termo elaboração que encontramos nas traduções para o português (e também no francês), "não deve na nossa opinião, ser adotado; com efeito corresponde melhor aos termos alemães bearbeiten ou verarbeiten, que também encontramos nos textos freudianos; e por outro lado, a tonalidade de 'dar forma' que contém poderia inflectir o sentido de durcharbeiten".
} 
É por meio dessa perlaboração que a testemunha vai sendo deslocada do estado de choque e aos poucos será capaz de construir representações sobre o evento traumático ao ponto de suportar a lembrança daquele evento. Daí a necessidade de falar, mesmo quando as memórias são tão dolorosas e pouco claras, por isso o superstes sobrevive não só ao evento traumático, mas sobrevive, principalmente, às memórias que não desaparecem, mas passam a ser suportáveis.

Mas se o testemunho perlaborado pelo narrador testis está marcado pela impossibilidade de narrar, no discurso do narrador superste essa impossibilidade se torna mais evidente, pois a “necessidade de contar 'aos outros', de tornar 'os outros' participantes, alcança entre nós, antes e depois da libertação, caráter de impulso imediato e violento, até o ponto de competir com outras necessidades elementares" (LEVI, 1988, pp. 7-8). A necessidade do testemunho passa de algum modo a se tornar vital para o sobrevivente que começa a conflitar com as necessidades vitais da vida humana, como beber, comer, dormir... Por isso encontramos nos testemunhos a insistência em narrar, mesmo quando parece impossível ou improvável, por conta das memórias serem confusas e a lembranças aterradoras.

Para dar conta de realizar o testemunho, o narrador, seja ele testis ou superste ${ }^{4}$, precisa perlaborar seu testemunho a partir do domínio dessas necessidades, pois enquanto esse narrador não conseguir suportar o desamparo diante da obtusa retirada de seus direitos fundamentais terá extrema dificuldade de narrar. Em geral, a narração do sobrevivente o ajuda a se sentir menos culpado por estar vivo e testemunhar, acaba sendo a melhor forma de manter sua integridade. Por isso o narrador superste sabe o quanto é importante narrar, já que sua vida está intimamente ligada à experiência que viveu e que a experiência se encontra marcada pela memória do sobrevivente, tal como relata Levi:

não esqueci nunca mais, era esse: justamente porque o Campo é uma grande engrenagem para nos transformar em animais, não devemos nos transformar em animais; até num lugar como este, pode-se sobreviver, para relatar a verdade, para dar nosso depoimento; e, para viver, é essencial esforçar-nos por salvar ao menos a estrutura, a forma da civilização. (LEVI, 1998, p. 39)

Ambiguamente, o narrador superste oscila entre a necessidade de narrar e sua impossibilidade, mas quando consegue narrar, por meio da perlaboração da experiência traumática,

\footnotetext{
${ }^{4}$ Para entender melhor a diferença entre testis e superstes tomemos a diferenciação apresentada por Émile Benveniste em Le vocabulaire des instituitions Indo-européennes, quando considera que "On voit la différence entre superste et testis. Etymologiquement testis est celui que assiste en 'tiers' (*terstis) à une affaire où deux personnages sont intéressés; et cette conception remonte à la période indo-européenne commune. Un texte sanskrit énonce: 'toutes les fois que deux personnes sont em présence, Mitra est là en troisième': ainsi le dieu Mitra est par nature le 'témoin'. Mais superstes décrit le 'témoin' soit comme celui 'qui subsiste au-delà', témoin en même temps que survivant, soit comme 'celui qui se tient sur la chose', qui y est présent”. (BENVENISTE, 1969 p. 277)
} 
faz com que esta necessidade se torne o fundamento de sua sobrevivência, pois a relação entre o que ele vivenciou e o que precisa narrar parece ser um tanto biológica e revela a manutenção da natureza viva, diante das diversas experiências de morte.

A insuportabilidade da experiência vista, ouvida ou vivida é responsável por um conjunto bem mais complexo de narradores e de testemunhas do que a ambivalência proposta por Benveniste, testis e superstes. Como já vimos anteriormente, há espaço para pensamos a ampliação dessas categorias pelo fato de encontrarmos no testemunho do terceiro (testis) bem mais que a narrativa do outro, pois em várias desses testemunhos o narrador testis, narra também a sua experiência e oscila entre narrar a si e narrar a experiência do outro como se esta fosse a sua própria experiência. Algo semelhante se dá na narração testemunhal de um narrador superstes. Durante boa parte de sua narração, que deveria ser a narrativa de si, ela se transforma em uma narrativa do outro. Sem dúvida, nessa forma híbrida de narrativa se entrecruzam as experiências e as dificuldades em narrar.

Durante a narração, o terceiro (testis) se reveste em primeiro (superstes), pois inclui na narrativa do outro as suas próprias narrativas, seus próprios conflitos e sofrimentos. Ele deixa de lado a condição de espectador e passa a protagonista da cena ao se incluir ou incluir sua narrativa, junto ao que está sendo narrado. Vejamos como isso ocorre na experiência testemunhal de Primo Levi:

Sofríamos com a sede e o frio; a cada parada, gritávamos pedindo água, ou ao menos um punhado de neve, mas raramente fomos ouvidos; os soldados da escolta afastavam quem tentasse aproximar-se do comboio. Duas jovens mães, com crianças de peito, queixavam-se dia e noite implorando por água. Havia também a fome, a fadiga, a falta de sono, mas a mesma tensão nervosa as mitigava. As noites, porém, eram pesadelos sem fim.

São poucos os homens que sabem enfrentar a morte com dignidade, e nem sempre são aqueles de quem poderíamos esperar. Poucos sabem calar e respeitar o silêncio alheio. Frequentemente, o nosso sono inquieto era interrompido por brigas barulhentas e fúteis, por imprecações, por socos e pontapés largados às cegas, reagindo contra algum contato incômodo, mas inevitável. Então alguém acendia a chama mortiça de uma vela, revelando no chão um escuro fervilhar, uma massa humana confusa e contínua, entorpecida e sofrendo, erguendo-se aqui e acolá em convulsões repentinas, logo sufocadas pelo cansaço. (Grifos nossos) (LEVI, 1988, p. 16)

Notemos que a narrativa de Levi desde o início oscila entre a narrativa de si e a narrativa do outro. No excerto acima o autor primeiro narra o drama coletivo, para depois reportar-se à particularidade da história de duas jovens mães, quando "a mesma tensão nervosa as mitigava". Em outro ponto de sua narrativa ele assevera que "poucos sabem calar e respeitar o silêncio alheio", questionando as confusões que roubavam o sono, mas justificada pela própria condição desumana em que se encontravam "uma massa confusa e contínua, entorpecida e sofrendo, erguendo-se aqui e acolá em convulsões repentinas". Vimos que ao mesmo tempo, ocorre a narração de si e a narração do outro: 
ele inclui sua visão sobre a condição humana e sua própria experiência. Essa é a tônica de toda a narrativa, que oscila entre a narração do outro e sua própria narrativa. Claro que existe uma prevalência da narração do outro. Em É isso um homem? existe grande preocupação em narrar como seria impensável sobreviver diante de uma condição tão desumana, mas atrelado a isso Levi constantemente se questiona como foi possível ele próprio sobreviver. Vejamos outra passagem em que a narração do outro gera a narração de si:

A sua vida é curta, mas seu número é imenso; são eles, os "muçulmanos", os submersos, são eles a força do Campo: a multidão anônima, continuamente renovada e sempre igual, dos não-homens que marcham e se esforçam em silêncio; já se apagou neles a centelha divina, já estão tão vazios, que nem podem realmente sofrer. Hesitase em chamá-los vivos; hesita-se em chamar "morte" à sua morte, que eles já nem temem, porque estão esgotados demais para poder compreendê-la.

Eles povoam minha memória com sua presença sem rosto, e se eu pudesse concentrar numa imagem todo o mal do nosso tempo, escolheria essa imagem que me é familiar: um homem macilento, cabisbaixo, de ombros curvados, em cujo rosto, em cujo olhar não se possa ler o menor pensamento. (LEVI, 1988, p. 91)

Vemos que Levi durante o capítulo constrói sua narrativa na esperança de categorizar quem seriam os submersos e os salvos no campo de concentração, mas aos poucos vai deixando escapar que mesmo sabendo de certa separação tácita encontrada no campo, ela não fora suficiente para justificar quem sobrevive. A narrativa mostra como os "muçulmanos" são destratados e servem apenas como número, "a força do Campo, a multidão anônima, continuamente renovada e sempre igual, dos nãohomens". Essa condição humana descrita por Levi o persegue, apesar de não ter sido um "muçulmano". Essa imagem destroçada e desumana o acossa, pois “jazíamos num mundo de mortos e de fantasmas. O último vestígio de civilização desaparecera ao redor e dentro de nós”. (LEVI, 1988, p. 173).

Acreditamos que a composição apresentada entre dois tipos de testemunhos o testis e o superstes e seu entrelaçamento tenha ficado bem evidente, mas acreditamos na existência de mais uma forma de testemunho, que será apontada por Emile Benveniste quando opõe os vocábulos arbiter e testis, na medida em que arbiter representa a figura da testemunha que ouve e julga, sem ter participado daquela experiência. Em suma, é o juiz que vai analisar de fora o fato sem envolvimento direto com a cena e por isso sua presença não seria notada. Nesse sentido, o arbiter, o árbitro, o juiz, na condição de testemunha (auricular) conhece o fato somente graças aos testemunhos primários do que vê ou vive. Podemos dizer que aqui constrói-se diante do narrar um trabalho de ajuizamento, um arbeiter. Por se encontrar distante dos fatos, esse narrador tem o poder de discernir - e decidir - o que deve ou não ser considerado na cena testemunhal, realizando um trabalho de seleção mais evidente. De certa forma 
esse narrador precisa fazer o julgamento do que ouviu, para que assim possa transformar essas apreensões em linguagem, em testemunho.

É preciso deixar claro que não tratamos aqui o testemunho arbiter, como pensa o campo jurídico, pois na esfera jurídica, existe uma preocupação em extrair a verdade, para desvendar um crime e encontrar - e punir - os culpados. Apenas propomos pensar o testemunho arbiter como parte das perlaborações de um indivíduo que de certa maneira performatiza o trabalho de um juiz; um indivíduo que diante dos fatos a ele relatados, deve tomar decisões sobre a matéria recordativa e nesse percurso se faz necessário que ele ateste o testemunho a ele relatado e avalie se acata ou não os conteúdos narrados ou se os acata parcialmente. Dessa forma o testemunho construído na perspectiva arbiter precisamente funda-se sobre a ideia de juízo, na medida em que arbitra acerca da sobrevivência da matéria recordativa - o que deve sobreviver, como deve sobreviver, pois o narrador ao apreender aquilo que ouve, tentará transmitir o que considera a verdade, mas o contrário também é possível, pois se há algo que não entende ou não aceita, modelará seu testemunho para que o mesmo seja mais bem recebido pelos outros.

Temos clareza de que a arbitragem a qual me refiro se faz implicada na necessidade de construir continuidades de uma narrativa, e desse modo não se subjuga à verdade jurídica, que procura encontrar uma só versão dos fatos. Ela se aproxima bem mais da verdade estética, que casa com a necessidade de narrar, mesmo quando o seu envolvimento se resume a ser o interlocutor de um testemunho.

Benveniste salienta que o testemunho testis representa o ponto de vista de alguém que vê e é visto na cena dolorosa, sabe e conta sob seu ponto de vista, também decidindo o que é possível narrar, fazendo escolhas e julgando o que será narrado, mas dentro da esfera daquilo que viu ou o que pensa que viu. Todavia, esse narrador é diferente da perspectiva do testemunho arbiter na forma como propomos aqui, pois ele tem o poder de narrar enquanto conhecedor da experiência, sem precisar fazer qualquer questionamento sobre a narrativa. Entre o ver e o ouvir há certo antagonismo, mas neste caso temos um elemento novo na leitura do testemunho, pois "le testis est là au vu et au su des parties; l'arbiter voit et entend sans être vu" ${ }^{\prime 5}$ (BENVENISTE, 1969, p. 120).

Temos agora uma forma de testemunho constituída por um narrador que apenas ouviu a narrativa, o testemunhante, ou seja, aquele que valida o testemunho, ouvindo e vendo o testemunho e, por conta de ter ouvido o testemunho, é capaz de replicá-lo, avaliando a narrativa e selecionando para a sua nova narração o que lhe interessa narrar, seja essa narrativa feita pelo narrador testis ou superstes.

${ }^{5}$ Tradução minha: "o testis está lá e pode ser visto por todos; o arbiter vê e ouve, sem ser visto" 
É interessante observar que o narrador, pode até ser protagonista da narrativa, mas constrói seu testemunho não apenas pela sua memória, mas por um conjunto de memórias protéticas a sua, que foram narradas por um terceiro ao narrador, que a analisa e a constitui como sua memória.

Esse testemunho, por estar embebido de um teor subjetivo-recriativo evidente, fica fragilizado na esteira do Direito, mas não anulado, pois o direito analisa fatos e "lhe interessa a realidade efetiva dos fatos" (AMBRÓZIO, 2010, p. 406), daí a necessidade da figura do arbiter (o juiz) para mediar o testemunho. É por conta do valor relativo dos testemunhos que, no âmbito jurídico, temos certa marginalização do mesmo, o que se dá pelo fato de haver uma intensa preocupação em garantir que o testemunho represente a verdade única do fato, como destaca Eugênia Vilela (2012, p. 167):

Sob o ponto de vista histórico e jurídico, a lógica do discurso testemunhal supõe a constituição de um discurso verdadeiro onde a verdade se define, como vimos anteriormente, a uma perspectiva epistemológica (a verdade do testemunho em oposição ao erro) e sob uma perspectiva moral (a verdade do testemunho em oposição a mentira). Neste contexto o sentido do testemunho decorre de um dever de verdade onde a verdade é perspectivada como uma entidade lógica (específica de um discurso onde se sublinha a generalidade e a universalidade dessa verdade possível de ser enunciada) que se sustenta numa ideia de verdade enquanto entidade substancial. (Grifos da autora)

Considerar o testemunho parte do dever de verdade despreza uma das circunstâncias mais comuns ligado ao julgamento do testemunho, a capacidade de o mesmo sofrer interferência direta no próprio processo jurídico e/ou sofrer com sua própria subjetividade. Já observamos que o testemunho não pode ser considerado a verdade única, nem ao menos pode ser rotulado como mentira, pois olhar e ouvir o que se passou em uma cena repleta de possibilidades não é simples para ninguém, bem como a escolha do modo de narrar, se testis, superstes ou arbiter também não pode ser compreendida apenas como uma escolha simplesmente, ela é uma tarefa demasiadamente difícil para o narrador e um exercício de memória muito grande, que às vezes frustra até mesmo a quem dá o testemunho, por não ser possível narrar tudo como exatamente ocorreu, nem é esse o objetivo do testemunho.

Como ocorre nas duas outras formas do testemunho, o arbiter também apresenta oscilação entre aquele que sobreviveu e a narração de sua experiência (superstes), e aquele que viu e podia ser visto e narra a experiência do outro, que também é sua (testis); e o que viu e ouviu o sobrevivente ou a testemunha e arbitra uma recepção sobre a cena descrita pelo outro (arbiter).

Perguntamo-nos, então, sobre a importância do arbiter no âmbito do testemunho. A resposta que encontramos é que sem o arbiter não há testemunho, pois, de certa forma, todo 
testemunho precisa de um arbiter para reconhecê-lo como testemunho, além de que a condição arbiter já está indiciada na necessidade da audição, a necessidade de um outro que se disponha a receber o testemunho, independente do destino que dará a matéria recordativa recebida. Isso porque o testemunho necessita ser gerido na interação com o outro, em busca da partilha, mas também da legitimação do que está sendo narrado. Em muitos casos o arbiter é o próprio narrador testis ou o superstes, isso porque a narração testemunhal pode ser composta não somente pelo que vivi, ou vi, mas também pelo que me disseram. Vejamos um exemplo desse testemunho arbiter, narrado por Primo Levi:

Schepschel vive no Campo há quatro anos. Viu morrer ao redor de si dezenas de milhares de seus semelhantes (...) mas faz já muito tempo que deixou de pensar em si a não ser como num saco que necessita ser enchido periodicamente. Schepschel não é muito robusto, nem muito valente, nem muito mau; nem é particularmente astucioso; nunca conseguiu uma colocação que lhe desse um pouco de folga; (...)

(...) Sigi me disse que no intervalo do meio-dia já o viu cantar e dançar frente ao Bloco dos operários eslovacos, esperando receber alguma sobra de sopa.

Poderíamos ser levados a pensar em Schepschel com certa indulgente simpatia, como num coitado cujo espírito já abriga apenas uma humilde, elementar vontade de viver, e que sustenta valentemente a sua pequena luta para não sucumbir. Schepschel, porém, não constituía uma exceção: quando a oportunidade chegou, não hesitou em deixar açoitar Moischl (que fora seu cúmplice num roubo na cozinha), na vã esperança de adquirir méritos perante o Chefe do Bloco e de candidatar-se à função de lavador de panelas. (LEVI, 1988, p. 94)

A narração de Levi, que é um narrador superstes, pois narra sua vida no campo, se apresenta agora como um narrador testis, que narra a história de Schepschel, ou seja, narra a um outro no campo, entretanto essa narrativa só é possível por estar apoiada pelo depoimento de outro, (“Sigi me disse"). A escolha narrativa do episódio da cena de canto e dança, revela uma das inúmeras estratégias de sobrevivência. Levi poderia ter narrado outras, mas selecionou do testemunho de Sigi, o que para ele foi emblemático na construção psicológica de Schepschel, por isso, ele se põe na condição de um narrador arbiter, que avalia o testemunho por ele ouvido, já que "poderíamos ser levados a pensar", mas o narrador arbiter pensa e decide como irá caracterizar tais procedimentos em seu testemunho.

Para nós fica evidente a contribuição que trazemos aos estudos do testemunho, pois com o testemunho arbiter ampliamos as formas de classificar o testemunho. O testemunho arbiter encontra espaço para analisar o que se encontra fora da cena, ao construir a sua versão sobre ela. Essa mesma posição narrativa de arbiter vamos encontrar em narrativas da segunda geração, daqueles que de tanto ouvir os testemunhos de seus pais, avós, irmãos, amigos... são levados a narrar, a também fazer seu 
testemunho, com base em uma matéria recordativa ouvida, coletada, reconfigurada pelo tempo, pelo espaço, mas não menos verdadeira.

Muitos dos narradores arbiter estiveram presentes nos campos, mas não recordam o que viveram, pois eram muito crianças, tinham dois, três, quatro anos de idade. Sem dúvida, uma criança nessa idade teria pouca chance de testemunhar se não fossem as narrativas, os testemunhos de outros sobreviventes. Há casos em que a experiência traumática impediu com que o sobrevivente trouxesse a experiência à tona, mas a narração de outros, que estiveram lá e narram perante o sobrevivente, compõe sua memória, como memória protética, incluída pelo outro e aceita pelo sobrevivente.

$\mathrm{Na}$ medida em que esses sobreviventes narram suas histórias a partir das memórias de outrem, suas memórias são as delas, por que as assumem como suas, sentem que essas memórias lhe pertencem. Contemporaneamente, encontramos diversas narrativas testemunhais em que a narração, o testemunho, são arbiter, pensamos rapidamente em textos tanto ligados a Shoah, como A trégua, de Primo Levi; ...E o mundo silenciou, de Bem Abraham; A vida e a luta de uma sobrevivente do Holocausto, de Sabina Kustin; e Maus, de Art Spiegelman; quanto testemunhos ligados às ditaduras na América Latina, como Batismo de sangue, de Frei Beto; Nunca estuve sola, de Nidia Díaz; Infância roubada, organizado pela Comissão da Verdade de São Paulo; Tejas Verdes, de Hernán Valdés e Una sola muerte numerosa, de Nora Strejilevich, narrativas que analisaremos em outra oportunidade.

\section{REFERÊNCIAS}

AMBRÓSIO, Graziella. Psicologia do testemunho. In. Rev. Direito Econ. Socioambiental, Curitiba, v. 1, n. 2, p. 395-407, jul./dez. 2010.

ARISTÓTELES. Ética a Nicômaco; Poética. seleção de textos de José Américo Motta Pessanha. 4. ed., Col. Os pensadores; v. 2. São Paulo: Nova Cultural, 1991.

BENVENISTE, Émile. Vocabulaire dês intitutions indo-européenes: 2. Pouvoir, droit, religion. Paris: Les Editions de Minuit: 1969.

DIGESTO, Corpus Iuris Civilis - livro I / Equipe responsável: Coordenação e Tradução: Edilson Alkmim Cunha; Ant6nio Augusto Catão Alves. [et al.]. -- Brasília: TRF1, ESMAF, 2010.

FARIA, Ernesto. Dicionário escolar latino-português. Brasil: Ministério da Educação e Cultura/ $\begin{array}{llll}\text { Departamento Nacional de } & \text { Educação, } & \text { Disponível }\end{array}$ em:https://archive.org/stream/DicionarioEscolarLatinoPortuguesDoMecPorErnestoFaria1962/Dicion arioLatinoPortugus\#page/n0/mode/2up. Acesso em: 06/02/2019.

LAPLANCHE, J; PONTALIS, J. B. Vocabulário da Psicanálise. São Paulo: Martins Fontes, 1996. 
LEVI, Primo. A trégua. Tradução: Marco Lucchesi. São Paulo: Companhia das Letras, 2010.

MARTINS, Ana Paula Vosne. A medicina da mulher: visões do corpo feminino na constituição da Obstetrícia e da ginecologia do século XIX. Tese de doutorado. Campinas: Unicamp, 2000.

PLATÃO. A República. Tradução: Enrico Corvisieri. São Paulo: Nova Cultural, 1997.

RODOVALHO, Joselina Rodrigues. Perlaboração (durcharbeitung) um modo de resiliência (resilience) psíquica? Brasília, 2006.

SELIGMANN-SILVA, Márcio. Zeugnis e Testemonio: um caso de intraduzibilidade entre conceitos. Revista Letras. $\quad N^{\circ} 22 . \quad J u n / J a n$ 2001. Disponível em: https://periodicos.ufsm.br/letras/article/view/11829/7257. Acesso em: 06/02/2019.

SELIGMANN-SILVA, Márcio. Narrar o trauma: a questão dos testemunhos de catástrofes históricas. Revista Psic. Clin. Rio de Janeiro, Vol. 20, Nº 01, p. 65-82, 2008

VILELA, Eugênia. Do testemunho. Princípios: revista de Filosofia, v. 19, n. 31, Natal: Janeiro/Junho 2012, p. 141-179.

Recebido em 03 de novembro de 2018

Aceito em 28 de dezembro de 2018 